\title{
ESTIMATING THE POTENTIAL OF ACHIEVING SELF-RELIANCE BY ROOFTOP GARDENING IN CHIAYI CITY, TAIWAN
}

\author{
YI-HSUAN HSIEH, JUNG-TE HSU \& TING-I LEE \\ Department of Horticultural Science, National Chiayi University.
}

\begin{abstract}
More than half of the global population has chosen to live in urban areas than in rural areas. This results in issues on sustainable food provision in urban areas. Transporting vegetables and fruits from the countryside to the city while keeping them fresh consumes energy and causes loss. Given the cost, growing food in and around cities has never been a new thing. However, only recently, growing food on rooftops on a business scale to achieve self-reliance has increasingly gained attention. With current technological advances in horticulture and agriculture, it has become more likely to secure food provision by cultivating on urban rooftops. Only a few business scale cases reported in high-income societies with a high-density population or experiencing snowing winter can afford and justify the choice of such a high input as well as a high-yield cultivating system. In Taiwan, with a warm winter, it may be more feasible to apply this system because less energy input is required to achieve the same yield as compared to that required in places in temperate climates. By estimating the potential of a high-density city to achieve self-reliance through rooftop growing systems, decision-makers can have more insight into how the idea can be promoted. As of end 2016, Chiayi city has the second largest population density after the capital city. Thus, this research aims at assessing the potential to achieve self-reliance by growing food on rooftops in Chiayi. It analyzes the yields of four types of rooftop cultivating systems and estimates the production and consumption by using these systems on three types of rooftops in different land uses, namely commercial, educational and residential. The result shows that the best scenario for achieving self-reliance is the rooftop hydroponic greenhouse model operating at the commercial scale although this is not sustainable or practical for general households in Chiayi City.

Keywords: food security, roof garden, rooftop farms, scenario analysis, self-reliance, urban agriculture, urban farming, urban food system.
\end{abstract}

\section{INTRODUCTION}

Urban agriculture has been defined as growing food in and around cities [1]. As vegetables, fruits and other food stuff have to be kept fresh when transported from the countryside to the city, this results in costs on energy consumption and loss of production. Given the cost, growing food in and around cities has never been a new thing. As more than half of the global population has chosen to live in urban areas than in rural areas [2], farming in urban environments is increasingly gaining attention. To feed the growing urban population, urban agriculture has been considered an approach, not only to meet the food self-sufficiency of an entire city, but also to contribute to food security by providing more choices of fresh, nutritional and affordable food for the urban population and for low-income families, in particular [2].

However, lack of ground-level space is a common issue in urban agriculture. In particular, Asia is home to $53 \%$ of global urban population [2]. With a high population density and scarce land, these Asian cities need space-efficient approaches for urban farming. Growing vertically in and around cities is thus a potential solution for sustainable food provision in the urban environment. Leafy vegetables are suitable to be grown on urban rooftops as the required amount of substrates would not put too much weight on the roofs. With the technological advances in horticulture and agriculture, by employing hydroponics techniques for 
example, it becomes more feasible to secure food provision through cultivating on urban rooftops. In high-income countries with temperate climates, there are several hydroponic greenhouses built on rooftops operating on a commercial scale [3, 4]. Several commercial and non-commercial cases of rooftop farms in high-income societies [4] are introduced in the following sections. These cases having high-density population or experiencing snowing winter can afford and justify the choice of such a high input, as well as a high-yield cultivating system. Their productivity data are employed by this study to estimate the self-resilience of rooftop farming in four scenarios in Chiayi City. The potential production and consumption of a range of rooftop farms are evaluated at various scales in different land uses, namely commercial, educational and residential.

\section{ROOFTOP FARMS}

In Chicago, a catering company partnered with the Chicago Botanic Garden, to create a 2.5acre rooftop soil garden [5]. The Midwest's largest rooftop garden owned by the SAVOR, Chicago produces seasonal harvests that yield $8,000 \mathrm{lb}$ of fresh vegetables including beets, kale, carrots, lettuce, peppers, beans and herbs used in its local kitchens. It is assumed that the open-air soil farm can harvest for three seasons and thus yield 240,000 lb of fresh vegetables a year.

In North America, prestigious cases of rooftop gardening present the possibility to grow food on a commercial scale through both open-field and greenhouse systems. The Brooklyn Grange in New York, USA, is the world's largest rooftop ranch without greenhouse facilities (Fig. 1). It spans two rooftops, totalling 2.5 acre, and produces over 50,000 lb of organically grown vegetables each year [6]. One is the one-acre (43,000 $\mathrm{ft}^{2}$ ) Flagship Farm made up of 1.2 million $\mathrm{lb}$ of soil, and the other is the Navy Yard farm covering a 65,000 $\mathrm{ft}^{2}$ building.

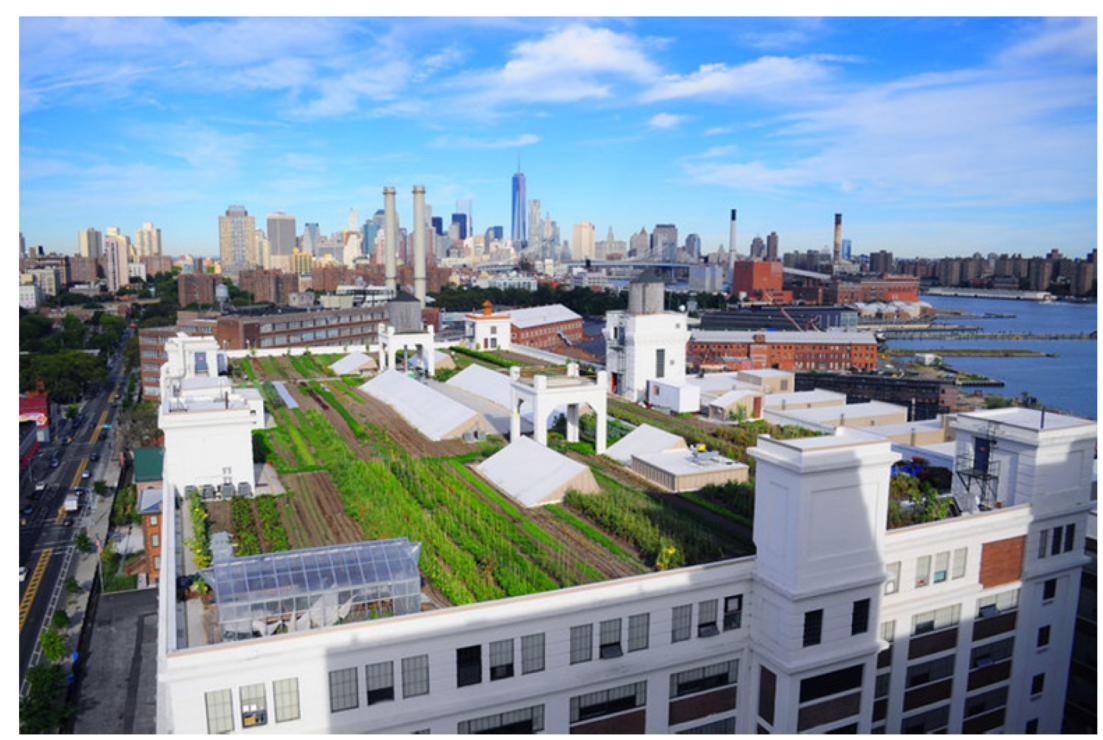

Figure 1: Brooklyn Grange is the leading rooftop farming and intensive green roofing business in the United States. It operates the world's largest rooftop soil farms, located on two roofs in New York City, and grows over 50,000 lbs of organically cultivated produce per year (Source: Brooklyn Grange [6]). 
Because these soil farms are exposed to temperate climate, they are farmed about 9 months of a year [6]. During winter, nitrogen-fixing 'cover crops', like clover and oats, are planted to add nutrients as well as to prevent erosion.

Greenpoint built in 2011 by Gotham Greens, represents another type of rooftop agriculture, growing on rooftops with greenhouse facilities (Fig. 2). The rooftop farm covers 3.75 acres and yields $220,000 \mathrm{lb}$ of fresh leafy vegetables per year [7]. This greenhouse hydroponics farm uses no chemical pesticides or herbicides but biotic-control methods, such as using the predators of pests to control the production loss. Also, it uses a recycled system for irrigation and employs solar energy as its main power source with special glasses and ventilation, so as to manage the water and energy resources wisely and sustainably. Later, in 2013, Gotham Greens went further by installing a greenhouse directly on top of a supermarket. The total growing area reached 5 acres and a yearly production of around 440,000 lb. The main products were leafy vegetables and tomatoes, which were grown from the rooftop farms and were directly sold in the supermarket housed under the farm. In this case, almost no transportation cost or carbon emission was generated. The success has encouraged Gotham Greens to expand their third greenhouse rooftop farm of 15 acres in 2015. They also plan to replicate the management model to Chicago for a 19-acre greenhouse farm, which can produce $10,000,000 \mathrm{lb}$ of fresh vegetables and fruits.

Montreal, Canada, also has rooftop farms. In 2011, Lufa Farms was the first to start a commercial-scale rooftop farm with greenhouse facilities in the world (Fig. 3). This greenhouse farm was built on top of a two-story building with an area of 8 acres growing 40 types of crops, including cucumber, chili, asparagus, and lettuce. The $32,000 \mathrm{ft}^{2}$ farm provides over 70 metric tons of food year-round to Montrealers [8]. The farm complies with the principles of sustainable management by using no green lands and no chemical fertilization or pesticides. Instead, it employs biological control methods, such as introducing ladybugs for aphid control. It also collects solar power worth 500,000 US dollars for the entire year through solar panels. Semi-transparent glasses are used to reduce heat loss. Furthermore, it combines the existing irrigation system and rain water used for irrigation and recycles $100 \%$ of irrigation water. This rooftop farm provides fresh vegetables and fruits for 3,000 people. Customers can purchase the produce by booking the amount and distribution points online in advance. Fresh

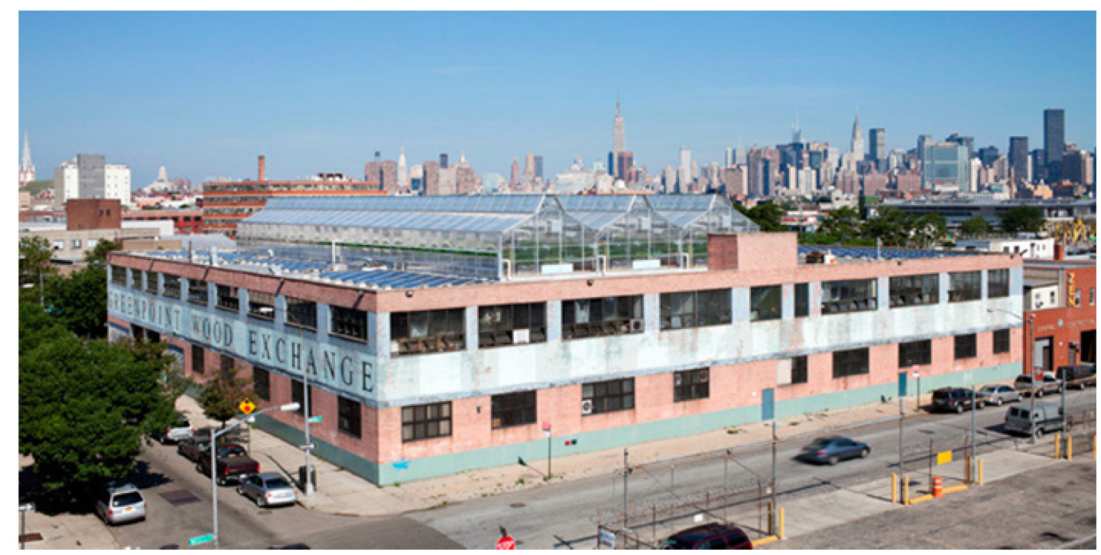

Figure 2: Greenpoint was the first commercial-scale greenhouse facility of its kind built in the United States. (Source: Gotham Greens [7]). 


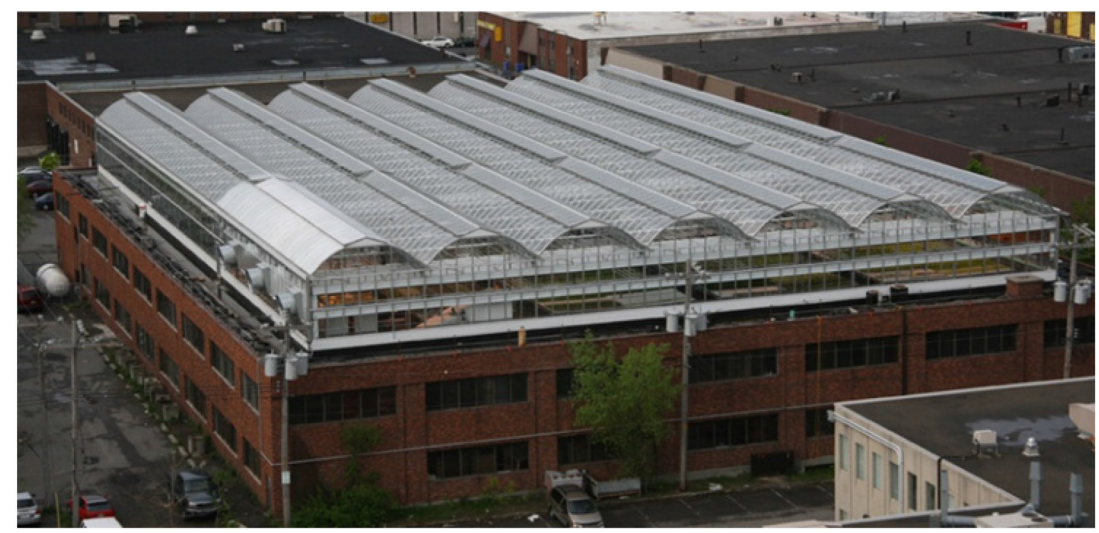

Figure 3: Lufa Farms's Ahuntsic greenhouse is the prototype and the world's first commercial rooftop greenhouse (Source: Lufa Farms [8]).

vegetables and fruits are distributed to certain locations for customers to collect on the harvest day.

Other than the business-oriented rooftop farms, there are also charity-oriented ones. Santropol Roulant [9], a Montreal-based non-profit organization, coordinates with the Montreal Municipal Government to deliver 'The Rooftop Garden Project [10]'. This nonprofit organization, which used to focus on delivering food for elderly disabled people, has now shifted to developing urban agriculture. It provides facilitation and support to the communities from knowledge to skills. Thus, the Montreal Municipal Government develops rooftop farms on the abandoned roofs of public buildings (Fig. 4). It now expands its scope by growing edible plants on the roofs and balconies of all levels of schools, local entrepreneurs, community centers and elderly housings with an aim to providing healthy and affordable organic vegetables for every community member.

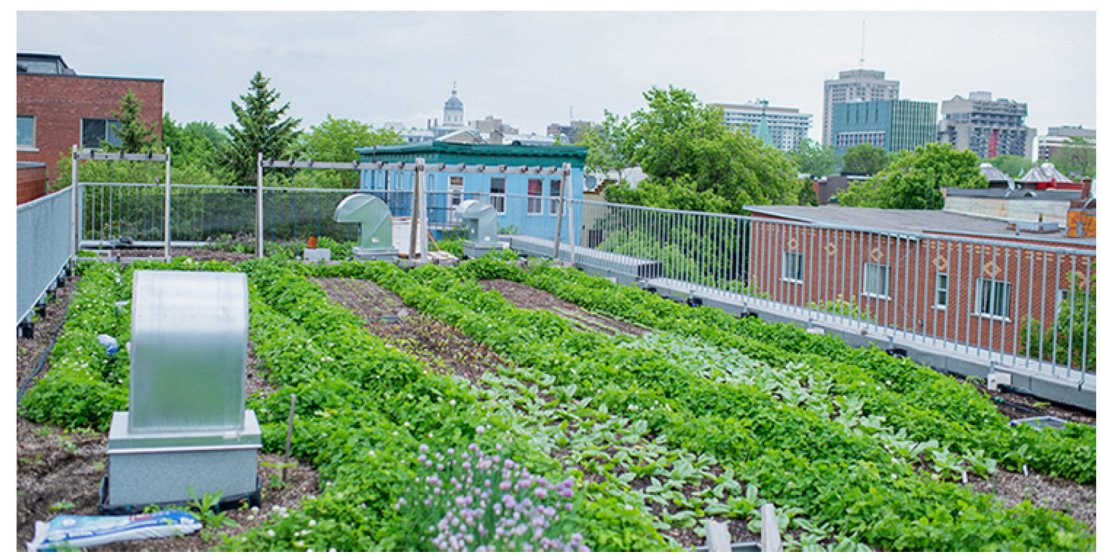

Figure 4: The Roulant's roof garden grows food and sends food to its kitchen for the charity food project. Kitchen scraps are composted in the basement and then used in the rooftop garden. (Source: Santropol Roulant [9]). 


\section{METHODS}

It is feasible to apply this system in Taiwan, which is in the subtropical climate zone with a warm winter, because less energy input is required to achieve the same yield as compared to that required in places in temperate climates. By estimating the potential of a high-density city to achieve self-reliance through rooftop growing systems, decision-makers can have more insight into how the idea can be promoted. As of end 2016, Chiayi city has the second largest population density after the capital city. Thus, this research assesses the potential of Chiayi City to achieve self-reliance by growing food on rooftops.

Given current policies and bylaws, available area, crop yields and human intake, Grewal and Grewal [11] evaluate the potential of food self-reliance of the City of Cleveland in three distinct scenarios. The degree of food self-reliance of a rooftop farm adapted from Grewal and Grewal [11] is calculated by the following equation:

$$
\% \text { Self }- \text { Reliance }=\frac{\text { Supply }}{\text { Needs }}=\frac{\text { Productivity } \times \text { Area }}{\text { Comsuption }} \times 100 .
$$

- \% Self-reliance is calculated by as the percentage of the fresh vegetable supply of a rooftop farm to the fresh vegetable needs of the farm.

- Supply is the assumed total fresh vegetable yield of the rooftop farm for a year.

- Needs is the projected consumption of fresh vegetables of the farm for a year.

Grewal and Grewal calculate the potential yields of a range of agricultural products, including fresh vegetables and fruits, poultry and shell eggs and honey on vacant lots, residential lots and even industrial and commercial rooftops. However, this study focuses on the crop yields of fresh vegetables on residential, educational and commercial rooftops. The annual productivity per unit area of rooftop farm is calculated by the following equation:

$$
\text { Productivity }=\text { Annual Yield } \div \text { Area } \text {. }
$$

- Annual Productivity is the total fresh vegetable yield per unit area of a rooftop farm for a year.

- Annual Yield is the total fresh vegetable yield of the rooftop farm for a year.

- Area is the coverage of the rooftop farm.

The annual productivity of fresh vegetables per unit area of rooftop gardens or farms is referred to four cases mentioned in the previous section. Greenhouse farms can produce year-round while open-air soil farms provide fresh vegetables for only 9 months or 3 seasons a year in the temperate climate zone. If the open-air method is applied to the sub-tropical climate zone, the open-air soil farms can also grow throughout the year. Therefore, for those open-air soil cases, two productivities based on both 9 and 12 months are calculated. Information on the rooftop cases and their productivity are provided as follows (Table 1):

1. SAVOR...Chicago, Chicago: $1.076032421 \mathrm{~kg} / \mathrm{m}^{2}$ for 9 months and $1.434689470 \mathrm{~kg} / \mathrm{m}^{2}$ for 12 months [5].

2. Brooklyn Grange, New York: $2.241733716 \mathrm{~kg} / \mathrm{m}^{2}$ for 9 months and $2.988951345 \mathrm{~kg} / \mathrm{m}^{2}$ for 12 months [6].

3. Greenpoint by Gotham Greens, New York: $6.575671119 \mathrm{~kg} / \mathrm{m}^{2}$ [7].

4. Supermarket by Gotham Greens, New York: $9.863506678 \mathrm{~kg} / \mathrm{m}^{2}$ [7]. 
Table 1: Annual yields under the productivity of four roof farm cases.

\begin{tabular}{|c|c|c|c|c|c|}
\hline Case Location & Scale & Type & $\begin{array}{l}\text { Area } \\
\text { (acre) }\end{array}$ & $\begin{array}{l}\text { Annual } \\
\text { Yield (lb) }\end{array}$ & $\begin{array}{l}\text { Annual Produc- } \\
\text { tivity per Unit } \\
\text { Area }\left(\mathrm{kg} / \mathrm{m}^{2}\right)\end{array}$ \\
\hline $\begin{array}{l}\text { 1. SAVOR...Chicago, } \\
\text { Chicago }\end{array}$ & Non-commercial & Open-air soil & 2.50 & $\begin{array}{l}24,000 \\
32,000\end{array}$ & $\begin{array}{l}1.076032421 \\
1.434689470\end{array}$ \\
\hline $\begin{array}{l}\text { 2. Brooklyn Grange, } \\
\text { New York }\end{array}$ & Commercial & Open-air soil & 2.50 & $\begin{array}{l}50,000 \\
66,667\end{array}$ & $\begin{array}{l}2.241733716 \\
2.988951345\end{array}$ \\
\hline $\begin{array}{l}\text { 3. Greenpoint by } \\
\text { Gotham Greens, } \\
\text { New York }\end{array}$ & Commercial & $\begin{array}{l}\text { Hydroponic } \\
\text { greenhouse }\end{array}$ & 3.75 & 220,000 & 6.575671119 \\
\hline $\begin{array}{l}\text { 4. Supermarket by } \\
\text { Gotham Greens, } \\
\text { New York }\end{array}$ & Commercial & $\begin{array}{l}\text { Hydroponic } \\
\text { Greenhouse }\end{array}$ & 5.00 & 440,000 & 9.863506678 \\
\hline
\end{tabular}

\section{SCENARIO ANALYSIS}

Three scenarios are selected for estimating the food self-reliance of Chiayi City at three scales and in three land use types. The annual yields of each scenario are calculated under four productivity abilities derived from four roof farm cases discussed earlier. Three scenarios represent roof farms on top of buildings in educational, commercial and residential land use, respectively:

1. Scenario I: the Chung-Wen Elementary School, Chiayi.

2. Scenario II: the Taiwan-based supermarket chain, PXMART.

3. Scenario III: the residential land use of Chiayi City.

\subsection{Elementary school scenario}

The first scenario is based on the condition of the Chung-Wen Elementary School, Chiayi (Fig. 5). The school has complied with the Chiayi City Government's policy of safe food by growing vegetables on an open-field farm. If the school wishes to achieve vegetable reliance, its rooftop can be transformed into a farm to maximize the provision for fresh vegetables for its students' lunch meal. For its own needs, the school has 1,960 students to feed fresh vegetables during lunchtime [12]. Given 159 school days a year and the recommended $175 \mathrm{~g}$ daily consumption of vegetables per student for school lunch, the need for vegetables for all students in the elementary school annually is $54,537 \mathrm{~kg}$.

The school has an area of $37,800 \mathrm{~m}^{2}$. With the building coverage ratio of $50 \%$ that has to be legally regulated for educational land, its roof can create a maximum area of $18,900 \mathrm{~m}^{2}$ for vegetable farming [13].

\subsection{Supermarket scenario}

The second scenario is based on the condition of a Taiwan-based supermarket chain, PXMART (Fig. 6). In 2002, the statistics of Taiwan Chain Stores and Franchise 


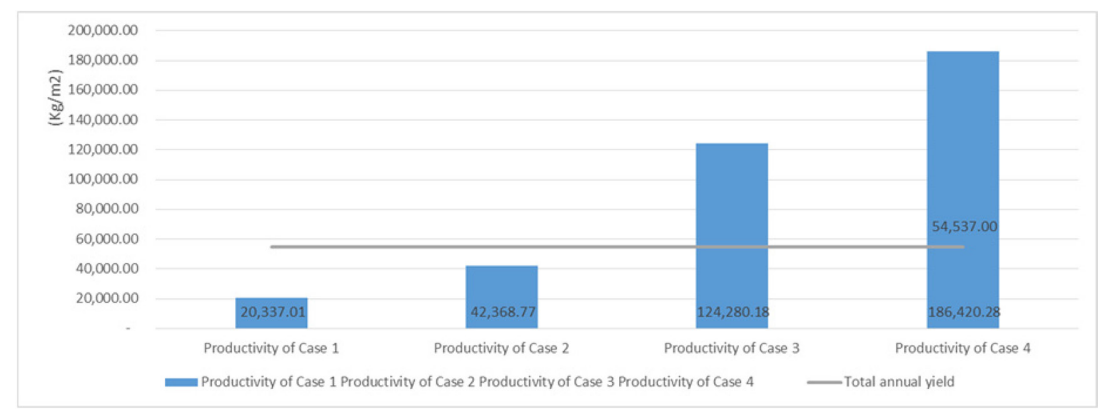

Figure 5: Needs and supply in the elementary school scenario.

Association (TCFA) showed that PXMART was most dominant with 178 stores and occupied $21.9 \%$ of the supermarket chains in Taiwan. The average area of a PXMART supermarket was $925.624 \mathrm{~m}^{2}$ in 2002, while supermarkets in Taiwan had an average area of $727.27 \mathrm{~m}^{2}$ excluding the area of their parking space and warehouses in 2003 [14]. In 2017, the total number of PXMART's chain stores has reached 846, among which, 708 stores sell fresh vegetables [15].

For its own requirement for 2017, PXMART reports an annual need of 68,315 tons of fresh vegetables and fruits, with 2,590 tons organically grown and 65,725 tons grown by contract farming. Thus, its food reliance can be examined by examining whether the needs can be met by growing vegetables on the roofs of their chain stores [15].

\subsection{City scenario}

The third scenario is based on the residential land use of Chiayi City (Fig. 7). As the total built-up residential area is $8,606,100 \mathrm{~m}^{2}$, with the building coverage ratio for residential use being $60 \%$, the maximum roof area of residential areas in Chiayi City can be up to $5,163,660 \mathrm{~m}^{2}$ [15]. These residential areas have a population of 265,556 people above 2 years [15] who are recommended to consume $300 \mathrm{~g}$ of vegetables a day. Thus, the assumed annual vegetable consumption for the population is $29,078,382 \mathrm{~kg}$.

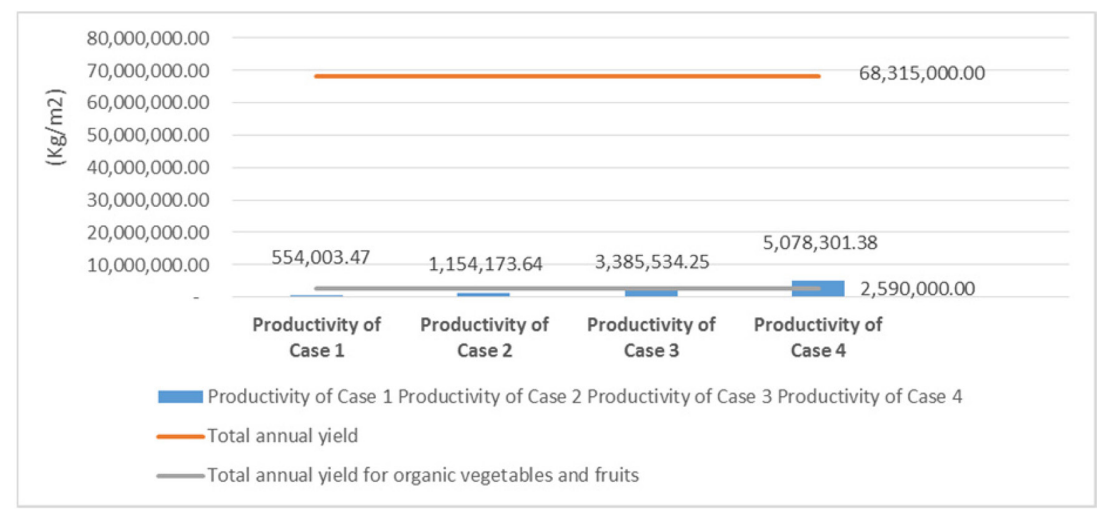

Figure 6: Needs and supply in the supermarket scenario. 


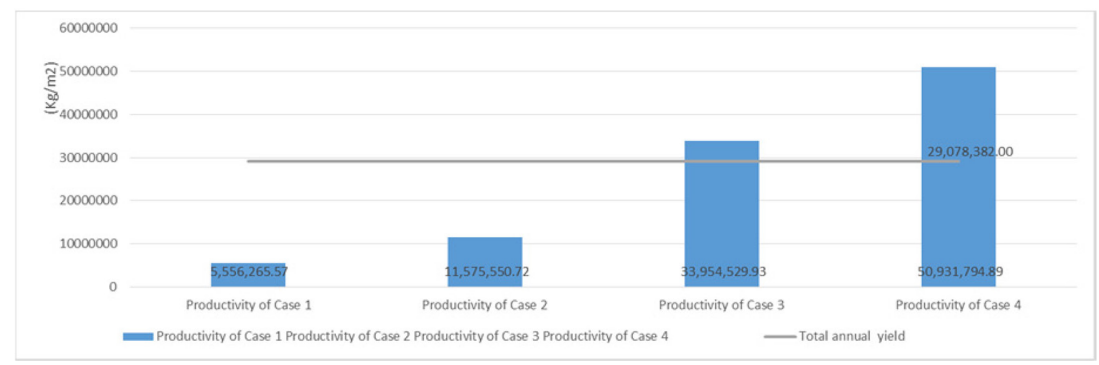

Figure 7: Needs and supply of the city scenario.

\section{VEGETABLE RELIANCE}

The vegetable reliance of each scenario is calculated (Table 2). Except for the entire vegetable needs of the supermarkets, a rooftop hydroponic farm operating on the commercial scale with greenhouse facilities can reach over $100 \%$ reliance of vegetables. This suggests that it is unlikely as well as pointless to fulfill all the vegetable needs of the supermarket through their rooftop farms. Thus, agriculture in the countryside still serves its important and irreplaceable role in food provision. For the supermarkets, their need for organic vegetables can be easily met by operating rooftop farms on top of their markets on a commercial scale with hydroponic greenhouses.

Although rooftop open-air soil farms operating on a non-commercial scale cannot fully meet the needs of any scenario, it still helps the elementary school scenario to reach $37.29 \%$ vegetable reliance. In addition, the rooftop area of the elementary school can be up to 4.67 acres, which is feasible for collaboration with hydroponic companies or professional

Table 2: The vegetable reliance of Scenario I, II and III under the productivity $\left(\mathrm{kg} / \mathrm{m}^{2}\right)$ of four roof farm cases.

\begin{tabular}{|c|c|c|c|c|c|c|}
\hline \multicolumn{3}{|c|}{ Scenarios } & $\begin{array}{l}\text { Productivity } \\
1\left(\mathrm{~kg} / \mathrm{m}^{2}\right): \\
1.076032421\end{array}$ & $\begin{array}{l}\text { Productivity } \\
2\left(\mathrm{~kg} / \mathrm{m}^{2}\right): \\
2.241733716\end{array}$ & $\begin{array}{l}\text { Productivity } \\
3\left(\mathrm{~kg} / \mathrm{m}^{2}\right): \\
6.575671119\end{array}$ & $\begin{array}{l}\text { Productivity } \\
4\left(\mathrm{~kg} / \mathrm{m}^{2}\right): \\
9.863506678\end{array}$ \\
\hline \multirow[t]{2}{*}{ I } & $\begin{array}{l}\text { Area }\left(\mathrm{m}^{2}\right) \text { : } \\
18,900.0\end{array}$ & $\begin{array}{l}\text { Supply } \\
(\mathrm{kg}) \text { : }\end{array}$ & $20,337.0$ & $42,368.8$ & $124,280.2$ & $186,420.3$ \\
\hline & $\begin{array}{l}\text { Needs }(\mathrm{kg}) \text { : } \\
54,537\end{array}$ & Reliance & $37.29 \%$ & $77.69 \%$ & $227.88 \%$ & $341.82 \%$ \\
\hline \multirow[t]{3}{*}{ II } & $\begin{array}{l}\text { Area }\left(\mathrm{m}^{2}\right) \text { : } \\
514,857.6\end{array}$ & $\begin{array}{l}\text { Supply } \\
(\mathrm{kg}) \text { : }\end{array}$ & $554,003.5$ & $1,154,173.6$ & $3,385,534.3$ & $5,078,301.4$ \\
\hline & $\begin{array}{l}\text { Needs }(\mathrm{kg}) \text { : } \\
68,315,000\end{array}$ & Reliance & $0.81 \%$ & $1.69 \%$ & $4.96 \%$ & $7.43 \%$ \\
\hline & $\begin{array}{l}\text { Organic Needs } \\
(\mathrm{kg}): 2,590,000\end{array}$ & Reliance & $21.39 \%$ & $44.56 \%$ & $130.72 \%$ & $196.07 \%$ \\
\hline \multirow[t]{2}{*}{ III } & $\begin{array}{l}\text { Area }\left(\mathrm{m}^{2}\right): \\
5,163,660.0\end{array}$ & $\begin{array}{l}\text { Supply } \\
(\mathrm{kg}) \text { : }\end{array}$ & $5,556,265.6$ & $33,954,529.9$ & $50,931,794.9$ & $11,575,550.7$ \\
\hline & $\begin{array}{l}\text { Needs (kg): } \\
29,078,382\end{array}$ & Reliance & $19.11 \%$ & $39.81 \%$ & $116.77 \%$ & $175.15 \%$ \\
\hline
\end{tabular}


organizations to create rooftop farms with greenhouse on a commercial scale. In this case, multiple purposes can be served by the rooftop farms.

\section{CONCLUDING REMARKS}

Providing food is not the only aspect that matters in urban agriculture. The findings reveal that none of the open-air soil farms on roofs can fully meet the needs of any scenario. However, to a certain extent, urban agriculture contributes to fresh food provision in urban environments and thus helps urban inhabitants to have access to fresh, safe, nutritious and affordable food. A rooftop farm is particularly meaningful to an educational organization even though it does not result in self-sufficiency.

Not surprisingly, analysis of the scenario reveals that hydroponic greenhouses on a commercial scale are most promising. However, the hydroponic growing model in reality is a highly energy-consuming and technology-intense plant factory. Its products are usually highend, and therefore less affordable. In this sense, the hydroponic vegetables grown on rooftop greenhouses are neither sustainable nor affordable.

In conclusion, growing vegetables on soil roof farms can hardly reach $100 \%$ self-reliance while growing vegetables hydroponically on rooftop greenhouses can easily achieve $100 \%$ self-reliance. However, considering the multiple purposes of growing food in and around cities, the open-air soil model is still the most sustainable and practical type of rooftop farms in Chiayi City despite the fact that it creates a much lower food self-reliance than the hydroponic greenhouse model.

\section{REFERENCES}

[1] Urban agriculture; Food and Agriculture Organisation of the United Nations (FAO), available at http://www.fao.org/urban-agriculture/en/ (accessed 27 February 2017)

[2] United Nations, World Urbanization Prospects-The 2014 Revision, Department of Economic and Social Affairs: New York, 2014.

[3] Halais, F., Can urban agriculture work on a commercial scale? available at: http:// citiscope.org/story/2014/can-urban-agriculture-work-commercial-scale.2014-08-21 (accessed 26 February 2017)

[4] Chen, B.R., Shorten the distance between urbanites and agriculture- farms are growing on rooftop of New York and Montreal, Taipeiecon, available at: http://www.taipeiecon. taipei/article_cont.aspx?MmmID=1203\&MSid=654073544642016307.2015-07-01 (accessed 21 February 2017) (In Chinese)

[5] SAVOR...Chicag, available at: http://savorchicagomcpl.com/. (accessed 25 February 2017)

[6] Brooklyn Grange, available at: www.brooklyngrangefarm.com/. (accessed 6 February 2017)

[7] Gotham Greens, available at: http://gothamgreens.com/our-farm (accessed 21 February 2017)

[8] Lufa Farms, available at: http://lufa.com/en/ (accessed 21 February 2017)

[9] Santropol Roulant, available at: http://santropolroulant.org/ (accessed 21 February 2017)

[10] The Rooftop Garden Project, available at: http://www.rooftopgardens.alternatives.ca/ (accessed 21 February 2017)

[11] Grewal, S. \& Grewal, P.C., Can cities become self-reliant in food? Cities, 29, pp. 1-11, 2012. 
[12] Chung-Wen Elementary School, available at: http://case.cy.edu.tw/web/cwesweb/ default.asp (accessed 2 March 2017) (In Chinese)

[13] Chiayi City Government, Revision of the Comprehensive Plan for Chiayi City, Second Edition, 2014. (In Chinese)

[14] Taiwan Green Productivity Foundation. Technic Guide of Energy-Saving for Supermarkets, available at: http://www.ecct.org.tw/Knowledge/knowledge_more?id=9a56fa954 4e24a50b4cba0036dfe545a 2003 (accessed 2 March 2017) (In Chinese)

[15] PXMART, available at: http://www.pxmart.com.tw/px/about_us_food_farm.px. 2014 (accessed 2 March 2017) (In Chinese) 